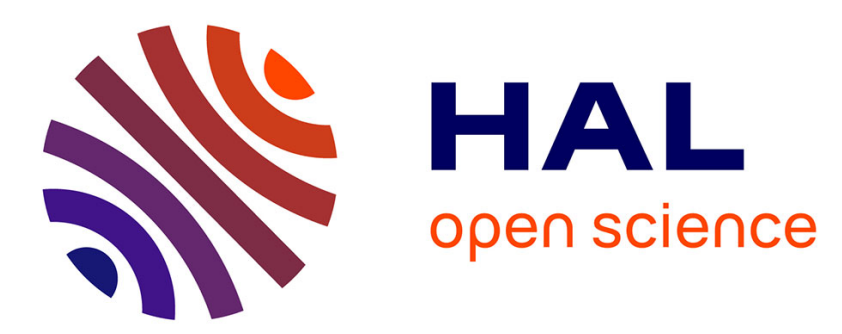

\title{
Inhibition of adhesion of Neisseria meningitidis to human epithelial cells by berry juice polyphenolic fractions
}

\author{
Marko Toivanen, Sanna Huttunen, Seppo Lapinjoki, Carina \\ Tikkanen-Kaukanen
}

\section{To cite this version:}

Marko Toivanen, Sanna Huttunen, Seppo Lapinjoki, Carina Tikkanen-Kaukanen. Inhibition of adhesion of Neisseria meningitidis to human epithelial cells by berry juice polyphenolic fractions. Phytotherapy Research, 2010, 10.1002/ptr.3349 . hal-00599840

\section{HAL Id: hal-00599840 \\ https://hal.science/hal-00599840}

Submitted on 11 Jun 2011

HAL is a multi-disciplinary open access archive for the deposit and dissemination of scientific research documents, whether they are published or not. The documents may come from teaching and research institutions in France or abroad, or from public or private research centers.
L'archive ouverte pluridisciplinaire HAL, est destinée au dépôt et à la diffusion de documents scientifiques de niveau recherche, publiés ou non, émanant des établissements d'enseignement et de recherche français ou étrangers, des laboratoires publics ou privés. 


\section{Inhibition of adhesion of Neisseria meningitidis to human epithelial cells by berry juice polyphenolic fractions}

\begin{tabular}{|r|l|}
\hline Journal: & Phytotherapy Research \\
\hline Manuscript ID: & PTR-10-0307.R1 \\
\hline Diley - Manuscript type: & Full Paper \\
\hline Author: & 07-Oct-2010 \\
\hline Complete List of Authors: & $\begin{array}{l}\text { Toivanen, Marko; University of Eastern Finland, School of Pharmacy } \\
\text { Huttunen, Sanna; University of Eastern Finland, Institute of Public } \\
\text { Health and Clinical Nutrition } \\
\text { Lapinjoki, Seppo; University of Eastern Finland, School of Pharmacy } \\
\text { Tikkanen-Kaukanen, Carina; University of Eastern Finland, Institute } \\
\text { of Public Health and Clinical Nutrition }\end{array}$ \\
\hline Keyword: & $\begin{array}{l}\text { berry polyphenols, meningococci, antiadhesion, epithelial cells, } \\
\text { antibacterial }\end{array}$ \\
\hline
\end{tabular}

\section{SCHOLARONE Manuscripts}



epithelial cells by berry juice polyphenolic fractions

3

4 Marko Toivanen ${ }^{1}$, Sanna Huttunen ${ }^{2}$, Seppo Lapinjoki ${ }^{1}$ and Carina Tikkanen-Kaukanen ${ }^{2}$

5

$6{ }^{1}$ School of Pharmacy, Faculty of Health Sciences, University of Eastern Finland,

$7 \quad$ Kuopio, Finland; ${ }^{2}$ Institute of Public Health and Clinical Nutrition, Faculty of Health Sciences, University of Eastern Finland, Kuopio, Finland

9

10 Correspondence to: Marko Toivanen, School of Pharmacy, Faculty of Health Sciences,

11 University of Eastern Finland, P.O. Box 1627, FI-70211 Kuopio, Finland. E-mail:

12 marko.toivanen@uef.fi; tel: +358-40-3552962; fax: +358-17-162424

13

14 Short title: Inhibition of meningococcal attachment 


\section{ABSTRACT}

16 Adhesion of pathogens to host tissues is the requirement for the initiation of the

17 majority of infectious diseases. We recently showed that the binding of Neisseria 18 meningitidis pili to immobilised human epithelial cells is inhibited by molecular size 19 fractions (10-100 kDa) of berry juices. Additionally, the isolated meningococcal pili 20 bound to polyphenolic fractions of berry juices. In the present study we investigated the 21 antiadhesive effects of berry juice polyphenolics against living meningococcal bacteria 22 in a human epithelial cell culture model. The ability of bilberry, cranberry, crowberry, 23 and lingonberry juice polyphenolic fractions to inhibit the attachment of $N$. meningitidis 24 bacteria to HEC-1B human epithelial cells in a cell culture model was examined. 25 Antibacterial effect of the fractions was tested using microtiter broth microdilution 26 assay. The most effective adhesion inhibition of $75 \%$ was achieved with cranberry juice 27 polyphenolic fraction followed by crowberry (63\%), bilberry (63\%), and lingonberry $28(57 \%)$ juice polyphenolic fractions. Bacterial survival rates after incubation with the 29 fractions varied between $75-100 \%$. The present results suggest berry juice polyphenols 30 as inhibitors of adherence of $N$. meningitidis. Thus the binding of meningococci to 31 berry juice polyphenols might be protective for the host against the infection.

33 Keywords: berry polyphenols; meningococci; epithelial cells; antiadhesion;

34 antibacterial 

INTRODUCTION

36

37

Meningitis caused by Neisseria meningitidis is a serious public health problem worldwide. The bacteria are transmitted from person to person through droplets of respiratory or throat secretions. $N$. meningitidis primarily infects human mucosal cell surfaces and colonises the nasopharyngeal epithelium. In Europe and the United States point-prevalence nasopharyngeal carriage rates have been estimated to range from 10 to $35 \%$ in young adults (Caugant and Maiden, 2009). There is no vaccine against the serogroup B which together with serogroup C accounts for a large majority of cases in Europe and in the Americas (Schwartz et al., 1989). Clinically the most important meningococcal phenotype is encapsulated (Carbonnelle et al., 2009). In encapsulated strains meningococcal adhesion to epithelial and endothelial cells occurs through type IV pili (Nassif et al., 1999; Pujol et al., 1997). The major neisserial pilus subunit, the pilin (Nassif and So, 1995) and the tip-located PilC1 protein (Nassif et al., 1994) are the potential adhesins.

One strategy to avoid bacterial infections could be antiadhesive agents which may prevent the attachment of infection causing bacteria to human cells. Unattached bacteria can be swept away by natural cleansing mechanisms of the host. Berries could be used as antiadhesives against binding of pathogenic bacteria to human epithelia. Cranberry polyphenols have been shown to be capable to inhibit the attachment of Escherichia coli (Gupta et al., 2007), Helicobacter pylori (Shmuely et al., 2004) and Streptococcus mutans (Weiss et al., 2004).

In our previous studies we have shown that N. meningitidis pili, Streptococcus pneumoniae bacterial cells and Streptococcus agalactiae bacteria bind to berry molecular size fractions especially from Vaccinium species and they inhibit 
59 hemagglutination caused by Streptococcus suis (Toivanen et al., 2009; Toivanen et al.,

60

61

62

63

64

65

66

67

68

69

70

71

72

73

74

75

76

77

78

79

80

81

\section{MATERIALS AND METHODS}

Berry juices. Bilberry (Vaccinium myrtillus L.), cranberry (Vaccinium oxycoccos L.), lingonberry (Vaccinium vitis-idaea L.) and crowberry (Empetrum nigrum \& E. hermaphroditum L.) (65 ${ }^{\circ}$ Brix, content of soluble solids $\mathrm{g} / 100 \mathrm{~g}$ of solution) juice concentrates were purchased from Kiantama Ltd (Suomussalmi, Finland). Juice concentrates contained no additives.

Chemicals. Methanol (VWR International Ltd., Leuven, Belgium) was of HPLC grade and ethyl acetate (Laboratory-Scan, Dublin, Ireland) was of analytical grade. Water was purified on a Millipore Milli-Q apparatus (Molshein, France). High-glucose DMEM, FBS, L-glutamine, trypsin-EDTA and sterile PBS were from Gibco (Paisley, U.K.) and ampicillin was from Sigma (St. Louis, MO). 
82 Isolation of berry juice polyphenols. Berry juice polyphenols were isolated as

83

84 described before (Toivanen et al., 2009). Briefly, berry juice concentrates were fractionated into three fractions according to their molecular size, i.e. $<10 \mathrm{kDa}$ fraction (referred as FI), 10-100 kDa fraction (FII) and >100 kDa fraction (FIII) using centrifugal filtering devices (Millipore Corp., Bedford, MA). The fractions FIII of the bilberry, cranberry and crowberry juices and the fraction FII of the lingonberry juice were further subfractionated using solid-phase extraction with C-18 SPE cartridge (Waters Corp., Milford, MA). Subfractions were eluted with ethyl acetate, water and methanol. The eluted subfractions were analysed using RP-HPLC-DAD. Subfractions (here polyphenolic fractions), which were eluted with water and contained anthocyanins and proanthocyanidins (Toivanen et al., 2009) were used in the inhibition experiments of the cell culture studies.

Bacterial strain and culture conditions. Neisseria meningitidis serogroup C class I strain 8013 (Nassif et al., 1993) (X. Nassif, INSERM U570, Paris) was cultured at 37 ${ }^{\circ} \mathrm{C}$ in $\mathrm{CO}_{2}$ atmosphere for $18 \mathrm{~h}$ on $\mathrm{GCB}$ agar (Oxoid Ltd., Basingstoke, England) containing Kellogg's supplement I and II (Kellogg et al., 1963.). After three washings with PBS $\left(2000 \times \mathrm{g}\right.$ at $4{ }^{\circ} \mathrm{C}$ for $\left.10 \mathrm{~min}\right)$ the absorbance of the bacterial suspension was adjusted to $\mathrm{A}_{600}=0,770$ and the bacteria were suspended to DMEM and diluted serially to $1: 1000$.

Cell culture. Adhesion of $N$. meningitidis has been tested using HEC-1B human epithelial cells as a model (Nassif et al., 1994). HEC-1B human epithelial cell line was obtained from X. Nassif (INSERM U570, Paris) and used between passages 11 and 28. 
106 Cells were cultured in cell culture dishes (Costar®, Corning Inc., Corning, NY) by 107 using $10 \mathrm{~mL}$ of high-glucose DMEM supplemented with $10 \%$ heat-inactivated FBS

108

109

110

111

112

113

114

115

116

117

118

119

120

121

122

123

124

125

126

127

128

Adhesion-inhibition assay. Berry juice polyphenolic fractions were diluted with cell culture medium to different concentrations between $0.5-50.0 \mu \mathrm{g} / \mathrm{mL}$. The diluted polyphenolic fractions $(1.5 \mathrm{~mL})$ were added on the overnight cultured HEC-1B cells and incubated over the cells for one hour at $37{ }^{\circ} \mathrm{C}$ in a humidified $5 \% \mathrm{CO}_{2} / 95 \%$ air incubator. The control wells were prepared by adding culture medium without polyphenolic fractions. Bacterial suspension $(1.5 \mathrm{~mL})$ was added to the wells (approx. $10 \mathrm{CFU}$ per one HEC-1B cell) and the wells were incubated for one hour at $37^{\circ} \mathrm{C}$. Nonadherent bacteria were removed by washing the wells twice with $3 \mathrm{~mL}$ of PBS. The cells were detached with trypsin-EDTA solution $(0.5 \mathrm{~mL})$ from the bottom of the wells. The detached cells were diluted 1:10 with PBS and 100 $\mu \mathrm{L}$ of the diluted cell samples was plated on the GCB agar plates. The plated bacteria were cultured overnight at $37{ }^{\circ} \mathrm{C}$ in $\mathrm{CO}_{2}$ atmosphere. The amount of the attached bacteria to the epithelial cells was determined by counting the bacterial colonies. The inhibitory activity of the berry juice polyphenolic fractions was calculated as follows: 
Inhibition $\%=\frac{C F U_{\text {control }}-C F U_{\text {sample }}}{C F U_{\text {control }}} \times 100$ where CFU is a colony forming unit

Antibacterial activity assay. Microtiter broth microdilution assay (Amsterdam, 1996) was chosen for testing the antibacterial activity of cranberry, bilberry, lingonberry and crowberry juice polyphenolic fractions against $N$. meningitidis because it has been of $<0.05$. described most suitable for plant extracts and phenolic compounds (King et al., 2008). Bacterial suspension and berry juice polyphenolic fractions in GC broth $(1.5 \%$ of

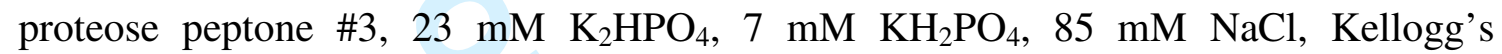
supplements I and II) were mixed together using the same amount of bacteria per berry polyphenolic fraction as in the adhesion-inhibition assay. The mixtures were incubated in wells of the microtiter plate strips (Nunc ${ }^{\mathrm{TM}}$, Brand Product, Roskilde, Denmark) at 37 ${ }^{\circ} \mathrm{C}$ in $\mathrm{CO}_{2}$ atmosphere for 2 hours. In control wells bacterial suspension was incubated with GC broth without adding berry juice polyphenolic fractions or by adding ampicillin $(100 \mu \mathrm{g} / \mathrm{mL})$. The antibacterial activity of the samples was measured by plating the incubation mixtures on GCB agar plates. The surviving colony forming units were counted next day. All the tests were made in duplicate.

Statistics. Statistical analysis was performed using GraphPad Prism 4.03 for Windows. One-way ANOVA followed by Dunnett's Multiple Comparison Test was performed to compare the amount of bacterial colonies between the control and the samples in the adhesion-inhibition assay. Inhibition of adhesion was considered significant at $P$ values

\section{RESULTS}


153 Adhesion-inhibition assay. Inhibitory activity of the bilberry juice polyphenolic

154 fraction was significant between the concentrations of $5-50 \mu \mathrm{g} / \mathrm{mL}$ and peaked at the 155 concentration of $10 \mu \mathrm{g} / \mathrm{mL}$ with the inhibition of $63 \%$ (Fig. 1a). The cranberry juice 156 polyphenolic fraction inhibited significantly meningococcal adherence to epithelial 157 cells, the inhibitory percent was $60-75 \%$ over the studied range of $1-50 \mu \mathrm{g} / \mathrm{mL}$ (Fig. 158 1b). Crowberry juice polyphenolic fraction showed significant inhibition from $47 \%$ to $15963 \%$ between the concentrations of $5 \mu \mathrm{g} / \mathrm{mL}$ and $50 \mu \mathrm{g} / \mathrm{mL}$, respectively (Fig. 1c). 160 Significant inhibition against meningococcal attachment with 56-57\% inhibition over 161 the studied range was seen with the lingonberry juice polyphenolic fraction, except $48 \%$ 162 inhibition at $25 \mu \mathrm{g} / \mathrm{mL}$ (Fig. 1d).

Antibacterial activity assay. Survival rates of $N$. meningitidis after incubation with three different concentrations $(1 \mu \mathrm{g} / \mathrm{mL}, 25 \mu \mathrm{g} / \mathrm{mL}$ and $50 \mu \mathrm{g} / \mathrm{mL})$ of the berry juice polyphenolic fractions are shown in Table 1. The lowest survival rates were detected with the cranberry juice polyphenolic fraction (75-90\% survival). Only slight or no antibacterial activity was seen when incubating meningococci with the polyphenolic fractions of the other berry juices. Bacterial survival with ampicillin control (100 $\mu \mathrm{g} / \mathrm{mL})$ was $45 \%$.

\section{DISCUSSION}

173 Inhibition of the bacterial attachment to human cells may offer a way to avoid infections 174 (Ofek et al., 2003). In the present study we showed bilberry, cranberry, crowberry and 175 lingonberry juice polyphenolic fractions containing anthocyanins and proanthocyanidins 176 (Toivanen et al., 2009) acting as antiadhesives. These fractions inhibited the attachment 
177 of $N$. meningitidis to epithelial cells in vitro. The results were generated using an 178 adhesion assay based on human epithelial cell line HEC-1B and living encapsulated meningococcal cells. The significant antiadhesion activity was achieved with relatively 180 low concentrations, $1 \mu \mathrm{g} / \mathrm{mL}$ of cranberry and lingonberry, and $5 \mu \mathrm{g} / \mathrm{mL}$ of bilberry and 181 crowberry juice polyphenolic fractions. Although the methodologies used in the experiments differ, the effective concentrations of the inhibition were on the same level as the concentrations in our previous microtiter well assay studies, where the isolated pili bound significantly to $0.39-12.5 \mu \mathrm{g} / \mathrm{mL}$ of these fractions (Toivanen et al., 2009). None of the studied berry juice polyphenolic fractions gave total inhibition for the attachment of meningococci and the highest inhibition was achieved up to $75 \%$ with the cranberry juice polyphenolic fraction with the concentration of $5 \mu \mathrm{g} / \mathrm{mL}$. In the binding assays with pili constant binding activity level was achieved at $50 \mu \mathrm{g} / \mathrm{mL}$ of polyphenolic fractions except $1.56 \mu \mathrm{g} / \mathrm{mL}$ of lingonberry juice polyphenolic fraction (Toivanen et al., 2009).

The important role of type IV pili is in colonisation and infection in encapsulated $N$. meningitidis strains (Nassif 2000). N. meningitidis has complex adhesion mechanisms and carries 2 potential adhesins in its type IV pili, the tip-located PilC1 (Rudel et al., 1995) and pilin (PilE) subunit proteins (Nassif et al., 1994). The mechanisms of PilE and PilC1 in epithelial cell binding are complicated, when encapsulated N. meningitidis interact with host cells in a multistep process (Nassif et al., 1999; Pujol et al., 1997). The concept of two different binding specificities located in two different components of the pilus is complicated by the fact that PilE undergoes antigenic variation (Meyer and van Putten 1989), which influences epithelial cell-specific adherence (Virji et al., 1993). Some pilin variants are more efficient than others in enhancing bacterial 
201 interactions and forming large bundles with enhancement of adhesiveness (Marceau et 202 al., 1995). The inhibition of the adhesion achieved in the present study by the berry 203 juice polyphenolic fractions may result either from pilin and/or PilC1 mediated 204 adhesion.

205 Berries and their phenolics have been shown to inhibit the growth of human 206 pathogenic bacteria (Puupponen-Pimiä et al., 2005). In the present study the bacterial 207 survival rates were above $90 \%$ for all samples with the exception that cranberry juice 208 polyphenolic fraction at $1 \mu \mathrm{g} / \mathrm{mL}$ induced $85 \%$ survival and at $50 \mu \mathrm{g} / \mathrm{mL}$ induced $75 \%$ 209 survival (Table 1). At these concentrations adhesion inhibition was $74 \%$ and $60 \%$, 210 respectively. Thus, the inhibitory effect of cranberry juice polyphenolic fraction can 211 partly result from the antibacterial effect of the fraction. For the other samples the 212 inhibitory effect achieved did not result from antibacterial effect but from the inhibition 213 of bacterial attachment.

214 Antiadhesive agents do not act by killing the pathogens so the spread of bacterial 215 strains resistant to antiadhesive agents will likely occur at a significantly lower rate 216 compared to antibiotic-resistant strains (Ofek et al. 2003). Small proportion of the 217 bacteria may be mutants resistant to antiadhesive agent. In only a few people the mutant 218 propagate, while in majority of cases bacteria bind to antiadhesive agents and are swept 219 away, and hence slowing down the spread of resistant strains.

220 Bacteria may also start to express new adhesins which bind to different receptors. 221 Therefore a single agent that has a broad spectrum of antiadhesion activity or a mix of 222 different antiadhesive agents that target several adhesins may be necessary.

223 Our results indicate that it could be possible to use berry juice polyphenols as 224 antiadhesives against $N$. meningitidis. Molecules may provide multiple binding sites for 
$225 N$. meningitidis pili adhesins and thus inhibit adhesion. Investigated polyphenolic water 226 extracts could be utilized easily. However, further purification of polyphenols will be 227 needed to find out if the antiadhesive effect can be related to a single molecule or the 228 effect needs synergic work of several berry molecules. Clinical trials will be necessary 229 to prove the effect of berry juice polyphenols against meningococcal attachment to 230 human nasopharynx and possible decrease in carrier rate.

231

232 ACKNOWLEDGMENTS

233 We thank Kiantama Ltd. (Suomussalmi, Finland) for providing berry juices, Xavier 234 Nassif for the bacterial strain and HEC-1B cells, and Sari Ukkonen for skilful technical 235 assistance.

236 This work was supported by the European Regional Development Fund and the Finnish 237 Funding Agency for Technology and Innovation (TEKES), grant number 70031/06 and 238 the Academy of Finland.

240 CONFLICT OF INTEREST

$241 \quad$ None to declare.

243 REFERENCES

244 Amsterdam D. 2005. Susceptibility Testing of Antimicrobials in Liquid Media. In 245 Antibiotics in Laboratory Medicine, Loman V (ed). Lippincott Williams \& Wilkins: 246 Philadelphia, PA, USA; 61-143.

247 Carbonnelle E, Hill DJ, Morand P, Griffiths NJ, Bourdoulous S, Murillo I, Nassif X, 248 Virji M. 2009. Meningococcal interactions with the host. Vaccine 27S: B78-B89. 
249 Caugant DA, Maiden MCJ. 2009. Meningococcal carriage and disease - Population 250 biology and evolution. Vaccine 27S: B64-B70.

251 Gupta K, Chou MY, Howell A, Wobbe C, Grady R, Stapleton AE. 2007. Cranberry 252 products inhibit adherence of P-fimbriated Escherichia coli to primary cultured bladder 253 and vaginal epithelial cells. J Urol 177: 2357-2360.

254 Kellogg DS, Peacock WL, Deacon WE, Brown L, Pirkle CI. 1963. Neisseria 255 gonorrhoeae. I. Virulence genetically linked to clonal variation. J Bacteriol 85: 12742561279.

257 King T, Dykes G, Kristianti R. 2008. Comparative evaluation of methods commonly 258 used to determine antimicrobial susceptibility to plant extracts and phenolic compounds. $259 \quad J$ AOAC Int 91:1423-1429.

260 Marceau M, Beretti J-L, Nassif X. 1995. High adhesiveness of encapsulated Neisseria 261 meningitidis to epithelial cells is associated with the formation of bundles of pili. Mol 262 Microbiol 17: 855-863.

263 Meyer TF, van Putten JPM. 1989. Genetic mechanisms and biological implications of 264 phase variation in pathogenic Neisseriae. Clin Microbiol Rev 2: S139-S145.

265 Nassif X. 2000. A furtive pathogen revealed. Science 287: 1767-1768.

266 Nassif X, Beretti J-L, Lowy J, Stenberg P, O’Gaora P, Pfeifer J, Normark S, So M. 267 1994. Roles of pilin and PilC in adhesion of Neisseria meningitidis to human epithelial 268 and endothelial cells. Proc Natl Acad Sci U.S.A. 91: 3769-3773.

269 Nassif X, Lowy J, Stenberg P, O’Gaora P, Ganji A, So M. 1993. Antigenic variation of 270 pilin regulates adhesion of Neisseria meningitidis to human epithelial cells. Mol 271 Microbiol 8: 719-725. 
272 Nassif X, Pujol C, Morand P, Eugène E. 1999. Interactions of pathogenic Neisseria with 273 host cells. Is it possible to assemble the puzzle? Mol Microbiol 32: 1124-1132.

274 Nassif X, So M. 1995. Interaction of pathogenic Neisseriae with nonphagocytic cells. 275 Clin Microbiol Rev 8: 376-388.

276 Ofek I, Hasty DL, Sharon N. 2003. Anti-adhesion therapy of bacterial diseases: 277 prospects and problems. FEMS Immunol Med Microbiol 38: 181-191.

278 Pujol C, Eugène E, de Saint Martin L, Nassif X. 1997. Interaction of Neisseria meningitidis with a polarized monolayer of epithelial cells. Infect Immun 65: 4836280 4842.

281 Puupponen-Pimiä R, Nohynek L, Hartmann-Schmidlin S, Kähkönen M, Heinonen M, 282 Määttä-Riihinen K, Oksman-Caldentey K-M. 2005. Berry phenolics selectively inhibit 283 the growth of intestinal pathogens. J Appl Microbiol 98: 991-1000.

284 Rudel T, Scheuerpflug I, Meyer TF. 1995. Neisseria PilC protein identified as type-4 285 pilus tip-located adhesin. Nature 373: 357-359.

286 Schwartz B, Moore PS, Broome CV. 1989. Global epidemiology of meningococcal 287 disease. Clin Microbiol Rev 2: S118-S124.

288 Shmuely H, Burger O, Neeman I, Yahav J, Samra Z, Niv Y, Sharon N, Weiss E, 289 Athamna A, Tabak M, Ofek I. 2004. Susceptibility of Helicobacter pylori isolates to the 290 antiadhesion activity of a high-molecular-weight constituent of cranberry. Diagn 291 Microbiol Infect Dis 50: 231-35.

292 Toivanen M, Huttunen S, Duricová J, Soininen P, Laatikainen R, Loimaranta V, 293 Haataja S, Finne J, Lapinjoki S, Tikkanen-Kaukanen C. 2010. Screening of binding 294 activity of Streptococcus pneumoniae, Streptococcus agalactiae and Streptococcus suis 295 to berries and juices. Phytother Res 24: S95-S101. 
296 Toivanen M, Ryynänen A, Huttunen S, Duricová J, Riihinen K, Törrönen R, Lapinjoki

297 S, Tikkanen-Kaukanen C. 2009. Binding of Neisseria meningitidis pili to berry 298 polyphenolic fractions. J Agric Food Chem 57: 3120-3127.

299 Weiss EI, Kozlovsky A, Steinberg D, Lev-Dor R, Greenstein RBN, Feldman M, Sharon 300 N, Ofek I. 2004. A high molecular mass cranberry constituent reduces mutans 301 streptococci level in saliva and inhibits in vitro adhesion to hydroxyapatite. FEMS 302 Microbiol Lett 232: 89-92.

303 Virji M, Saunders JR, Sims G, Makepeace K, Maskell D, Ferguson DJ. 1993. Pilus304 facilitated adherence of Neisseria meningitidis to human epithelial and endothelial cells: 305 modulation of adherence phenotype occurs concurrently with changes in primary amino 306 acid sequence and the glycosylation status of pilin. Mol Microbiol 10: 1013-1028. 
Table 1. Survival of Neisseria meningitidis after incubation with berry juice polyphenolic fractions.

\begin{tabular}{ccccc}
\hline $\begin{array}{c}\text { Concentration of } \\
\text { polyphenols }(\mu \mathrm{g} / \mathrm{mL})\end{array}$ & $\begin{array}{c}\text { Bilberry } \\
\text { juice }\end{array}$ & $\begin{array}{c}\text { Cranberry } \\
\text { juice }\end{array}$ & $\begin{array}{c}\text { Crowberry } \\
\text { juice }\end{array}$ & $\begin{array}{c}\text { Lingonberry } \\
\text { juice }\end{array}$ \\
\hline 1 & $90 \%$ & $85 \%$ & $\geq 100 \%$ & $\geq 100 \%$ \\
25 & $100 \%$ & $90 \%$ & $100 \%$ & $100 \%$ \\
50 & $100 \%$ & $75 \%$ & $100 \%$ & $\geq 100 \%$ \\
\hline
\end{tabular}

Ampicillin $(100 \mu \mathrm{g} / \mathrm{mL}): 45 \%$ 


\section{FIGURE LEGEND}

FIGURE 1. Inhibition of the attachment of Neisseria meningitidis to HEC-1B cells by bilberry (a), cranberry (b), crowberry (c), and lingonberry (d) juice polyphenolic fractions. The values represent the mean and standard deviation calculated from at least three experiments. Significant difference $(P<0.05)$ in inhibition compared to control is marked with *. 
Toivanen M, FIGURE 1
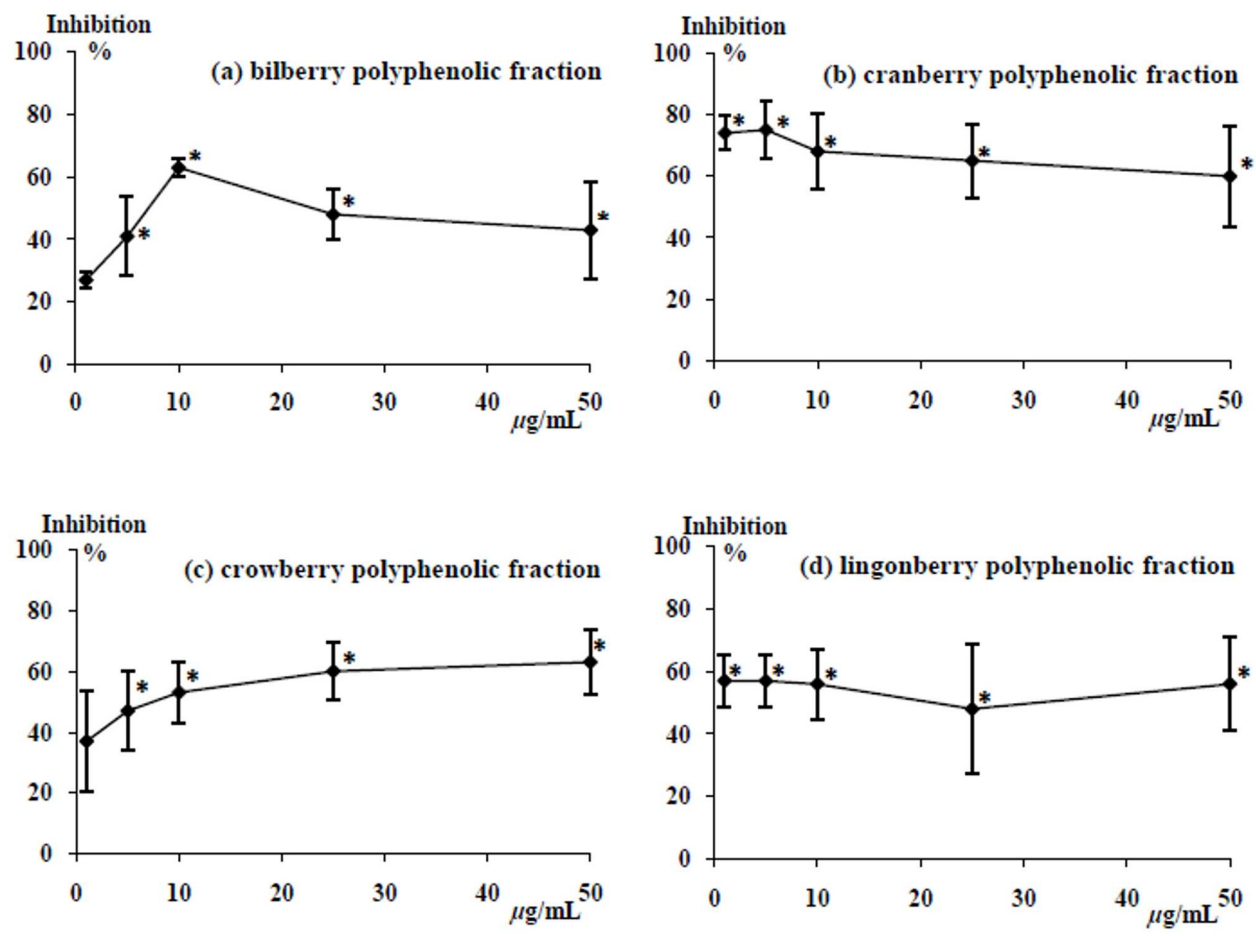

$175 \times 143 \mathrm{~mm}(600 \times 600$ DPI $)$ 